\title{
O CARÁTER ANTIRREPRESENTACIONALISTA DA COGNIÇÃO NO PENSAMENTo De Merleau-Ponty
}

\author{
Gilbert Cardoso Bouyer ${ }^{1}$
}

\begin{abstract}
Resumo: Este artigo defende o ponto de vista de que as bases da ciência cognitiva contemporânea (CC) estão em sintonia com o pensamento de Merleau-Ponty, em seus aspectos antiobjetivista e antirrepresentacionalista. A ideia de representaçáo mental é contestada, tanto na CC quanto no pensamento de Merleau-Ponty. A cognição não espelha um mundo exterior independente dos sujeitos incorporados. O mundo é um existencial, como afirmam Merleau-Ponty e a CC. A hipótese da representação mental supóe que o mundo pode ser percebido de forma independente do sujeito que percebe. Isso não é verdade. A percepção depende da forma como o sujeito age em seu mundo percebido. Todas as estimulaçóes que o organismo encontra só são possíveis pelos seus movimentos precedentes que resultam na exposição do órgão receptor às influências externas. Os estímulos sensoriais que o organismo encontra dependem diretamente do seu comportamento motor e a forma como o organismo se move depende diretamente das consequências sensoriais dos seus comportamentos anteriores.
\end{abstract}

Palavras-chave: Merleau-Ponty. Representação mental. Ciência cognitiva.

\section{INTRODUÇÁo}

A obra de Merleau-Ponty se tornou, nos últimos anos, uma base de sustentação da ciência cognitiva contemporânea (CC). A CC afirma que a mente humana não funciona com base em representaçóes mentais, num modelo de processamento simbólico de informaçóes. Ao invés do modelo representacionalista, tem-se um modelo da cognição incorporada. Sustentamos, neste texto, que os mesmos pressupostos da cogniçáo incorporada presentes na CC estão visíveis na obra de Merleau-Ponty.

Há, portanto, dois pontos de vista contraditórios no debate sobre o funcionamento da cognição humana. Um deles, já derrubado pela CC,

${ }_{1}^{1}$ Professor Associado da Universidade Federal de Ouro Preto - UFOP, Ouro Preto, Minas Gerais Brasil. (D) https://orcid.org/0000-0002-2671-5966 E-mail: gilbertcb@uol.com.br.

http://doi.org/10.1590/0101-3173.2020.v43esp.11.p145

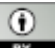

This is an open-access article distributed under the terms of the Creative Commons Attribution License. 
é o cognitivismo (representação mental e processamento simbólico de informaçóes). O outro, da cognição incorporada, vigente na CC. Veremos como esses pontos de vista se excluem mutuamente e como eles surgem no pensamento de Merleau-Ponty e na CC.

O comportamento é algo determinante para a percepção. É pelo comportamento que o agente define o seu universo perceptivo, enquanto causa primeira de todas as estimulaçóes. Sou eu que defino, no meio, a quais estímulos eu serei sensível. Isso derruba a hipótese de um agente processador de estímulos e emissor de outputs como no realismo representativo (representacionalismo). A hipótese do representacionalismo (realismo representativo) não é "verdadeira", tendo sido derrubada na fenomenologia por Merleau-Ponty, dentre outros, e na ciência pela Ciência Cognitiva. No caso da Ciência Cognitiva, esta se pauta inclusive por experimentos controlados (típico de uma ciência madura) para fazer valer a tese da cognição incorporada (antirrepresentacionalista) e afastar por completo a hipótese do realismo representativo.

As noçóes de "comportamento" e de Umwelt são ambas centrais na argumentação aqui presente. Tema de intensos debates entre os estudiosos, elas apresentam uma complexidade dificilmente redutível a uma significação única. Ora, como vimos anteriormente, o comportamento é a causa primeira de todas as estimulaçóes, e o Umwelt é esse ambiente de recorte criado pelo comportamento do agente. O agente cria o seu Umwelt pelo seu comportamento, pela sua ação incorporada ou, como diria Heidegger (2005), pelo seu ser-no-mundo.

O Umwelt é o mundo de sensoriomotricidade do sujeito-agente, que faz sentido, ou cria sentido, para ele sem necessitar passar por uma representaçáo mental. Trata-se do mundo de pertencimento do agente, no qual ele encontra sentido para suas açóes, mas um sentido sensoriomotor. O Umwelt poupa o agente de ter que elaborar uma representação mental para agir sobre o mundo, porque ele oferece as respostas necessárias num repertório de açóes possíveis que esse mundo de atuação permite.

\section{O COGNITIVISMO (REPRESENTACIONALISMO)}

Conforme Varela (1994), segundo a hipótese cognitivista, a inteligência e a cognição funcionam como um computador, definidas pela computação de representaçóes simbólicas: 
Que significa exatamente a ideia: a cognição pode ser definida por computação? O tratamento computacional é uma operação efetuada por símbolos, ou seja, por elementos que representam aquilo a que correspondem. [...] O argumento cognitivista é o de que o comportamento inteligente pressupóe a faculdade de representar o mundo de uma certa maneira. Assim, não podemos explicar o comportamento cognitivo sem presumir que um agente reaja, representando os elementos pertinentes das situaçôes em que se encontra. Na medida em que sua representação da situação é fiel, também o comportamento do agente será adequado, verificando-se, aliás, uma igualdade entre todas as coisas. [...] a hipótese cognitivista pretende que a única solução para explicar a inteligência e a intencionalidade reside na justificativa de que a cognição consiste em agir na base de representaçóes que têm uma realidade física sob a forma de código simbólico num cérebro ou numa máquina. (VARELA, 1994, p. 30-31).

Essa acepção de representação foi, no passado, aceita como válida na CC pretérita. A computação seria essencialmente simbólica, no sentido de que os símbolos possuem uma realidade simultaneamente física e semântica, sendo a computação condicionada por essa realidade semântica. E a cognição humana funcionaria desse modo. A computaçáo é, portanto, fundamentalmente representacionalista. No entanto, um computador somente manipula a forma física dos símbolos. Logo, para o cognitivista representacionalista, a cognição funciona pela computação física de símbolos. Porém, embora a dimensão simbólica contenha uma realidade física, ela não é redutível ao nível físico. O cognitivismo postula, portanto, um nível simbólico distinto e irredutível. Para o cognitivismo, cognição é tratamento de informação: a manipulação de símbolos a partir de regras. Ela funcionaria por meio da representação e manipulação de elementos físicos descontínuos: os símbolos.

O sistema interage apenas com os atributos físicos dos símbolos (sua forma) e não com seu sentido. Acredita-se que os símbolos são capazes de representar adequadamente qualquer aspecto do mundo real. $\mathrm{O}$ critério de avaliação da cognição é a representação adequada de um mundo exterior predeterminado. $\mathrm{O}$ mundo, tal como percebido, é independente daquele que percebe. Isso se choca com a noção de gênero (CLOT, 2006), pela qual a percepção de aspectos da atividade de trabalho depende de características do sujeito acoplado a um determinado gênero. $O$ gênero é definido por esse autor como um repertório de açóes possíveis de serem adotadas numa determinada situação, sem que o agente necessite representar, a cada momento, qual ação 
utilizar. Basta fazer uso do gênero. A relação entre sujeito e gênero é a de orientação. $O$ gênero orienta as açóes individuais.

Somente se valem de um mesmo gênero aqueles que partilham de um mesmo horizonte de ação. Estes vão ter percepções comuns sobre um mesmo aspecto da realidade e vão se valer delas, para efetuar sua ação. Um suporte coletivo e histórico para a ação individual, um interposto entre os sujeitos e entre estes e o objeto da atividade - eis o gênero:

Meio de ação para cada um, o gênero é também história de um grupo e memória impessoal de um local de trabalho. Diremos às vezes simplesmente gênero, para abreviar. Mas sempre se tratará das atividades ligadas a uma situação, das maneiras de "apreender" as coisas e as pessoas num determinado meio. A esse título, como instrumento social da ação, o gênero conserva a história. Ele é constitutivo, dessa perspectiva, da atividade pessoal que se realiza através dele. [...] um grupo não é uma coleção de indivíduos, mas uma comunidade inacabada cuja história define também o funcionamento cognitivo coletivo (CLOT, 2006, p. 38).

\section{ENAÇÁO: UMA ALTERNATIVA À REPRESENTAÇÃo}

A cognição não pode mais ser avaliada como a representação adequada de um mundo exterior predeterminado. Somente um mundo predefinido poderia ser representado. Mas não existe mundo predefinido. Sujeito e mundo são mutuamente especificados um pelo outro (THOMPSON, 2005). O conhecimento não é um espelho da natureza. Vários pensadores mais recentes reconheceram o equívoco da representação ou, nas palavras de Varela (1994, p. 73-74, grifos nossos):

Só nos mais recentes trabalhos de alguns pensadores continentais (particularmente M. Heidegger, M. Merleau-Ponty e M. Foucault) se dá início à crítica explícita da representação. Estes pensadores ocupam-se de todo o fenômeno da interpretaçáo no seu sentido circular de ligaçáo entre açáo e saber, entre aquele que sabe e o que é sabido. Referimo-nos a esta circularidade total da açáo/interpretaçáo através do termo fazer-emergir. Além disso, porque esta perspectiva analítica se preocupa especialmente em fazer predominar o conceito de ação sobre o da representação, convém chamar a esta nova abordagem de enação.

O conceito de representação criticado pela ciência cognitiva e pela fenomenologia é essencialmente o mesmo, conforme fica claro, na citação anterior de Francisco Varela, ao se referir a Heidegger, M. Merleau-Ponty 
e Foucault como pensadores que fizeram uma crítica explícita à noção de representação. Em toda a sua obra, em parceria com outros pesquisadores, Varela nada mais fez que criticar a ideia de representação mental, colocando como seu oposto a ideia de Enaçáo. Mais que isso, ele foi além demonstrando como essa ideia não se sustenta também na filosofia (fenomenologia). E podemos ir adiante, afirmando que o conceito de representação é igualmente criticado por Husserl, numa contumaz abordagem antirrepresentacionalista que percorre toda sua obra e é hoje naturalizada pela ciência cognitiva (PACHOUD, 1999). O termo "Naturalização da Fenomenologia de Husserl" implica precisamente isso. A noção de representação contestada pela Fenomenologia é o mesmo termo que é contestado na ciência cognitiva. Petitot, Varela, Pachoud e Roy (1999) empreendem uma crítica corrosiva à noção de representação, tanto na fenomenologia quanto na ciência cognitiva. O conceito de representação é o mesmo, quer na fenomenologia naturalizada, quer na ciência cognitiva.

Por conseguinte, o conceito de "representação", no sentido conferido ao termo nas $\mathrm{CC}$ e na computação, equivale ao sentido filosófico do conceito de "representação", tal como ele é explicitamente criticado por Merleau-Ponty, Husserl e Heidegger. Trata-se do mesmo conceito e não de conceitos diferentes.

O conhecimento está atrelado ao fato de ser o mundo inseparável do corpo do sujeito, de sua linguagem e de sua história social. Isso náo pode ser definido por um conjunto de regras e de pressupostos, porque depende da ação e da história. Não é possível ao sujeito (agente) excluir-se do mundo, para dele elaborar representaçóes que o espelhem, visto que sujeito e mundo são mutuamente especificados. Ele está imerso no mundo assim como o mundo está entranhado nele. Não existe uma representação pura do mundo, ideal, independente das estruturas ou esquemas do próprio sujeito. $\mathrm{O}$ contexto e o senso comum náo são artefatos residuais que possam ser eliminados, em prol de uma representação pura e fidedigna do mundo. O contexto - e, no caso, o gênero (CLOT, 2006) - são a própria essência da cognição criadora. Não existe representação do mundo exterior, mas sim uma cocriação de um mundo dependente do sujeito nele incorporado e de suas percepçôes. A afirmação de que o mundo, tal como é em si, é percebido pelo sujeito é falsa. $\mathrm{O}$ mundo não pode ser compreendido independentemente da história social do sujeito. Aquele que sabe e aquilo que é sabido, sujeito e objeto, são especificação recíproca e simultânea um do outro. Ou seja, o saber é ontológico.

A ideia de representação mental defende que o mundo é predefinido ou, em outras palavras, que suas propriedades existem antes da atividade cognitiva. 
Traz ainda a noção de que o mundo é, "em si", universalmente percebido e traduzido em representaçóes mentais idênticas por sujeitos distintos, o que viola a noção de gênero (CLOT, 2006). Segundo a enação, mundo e sujeito não preexistem um ao outro, porém, são mutuamente especificados, pelo processo histórico contínuo da vida, que moldou o mundo por meio de um vaivém entre a atividade exterior e a interior. Isso derruba de vez os extremos do objetivismo, do idealismo e do solipsismo.

A ideia fundamental é, pois, que as faculdades cognitivas estáo inextricavelmente ligadas ao historial da vivência, da mesma maneira que uma vereda anteriormente inexistente vai aparecendo conforme se caminha. A imagem da cognição que se segue não é a resolução de problemas por meio de representaçóes, mas sim o fazer-emergir criador de um mundo [...] a representaçáo já não tem um papel-chave, a inteligência já não se define como sendo a faculdade de resolver um problema, mas como a de penetrar num mundo partilhado (VARELA, 1994, p. 88-89).

\section{O ANTIRREPRESENTACIONALISMO DA CIÊNCIA COGNITIVA CONTEMPORÂNEA EM EvAN THOMPSON}

A hipótese da representação mental supóe que o mundo pode ser percebido de maneira independente do sujeito que percebe. Isso não é verdade. A percepção depende da forma como o sujeito age e se acopla ao seu mundo percebido (MERLEAU-PONTY, 2005) ou Umwelt. O Umwelt é o mundo de pertença do agente (aquele que age), tal qual em Uexküll. Trata-se do mundo criado pelo próprio agente em seu exercício de agir, algo como um universo gerado pela atuação. Já o comportamento é a causa maior de todas as estimulaçôes. É o agente que define aquilo que será sensível, nesse mundo de recorte, pelo seu próprio comportamento. O corpo fenomenal (MERLEAUPONTY, 2005) aí está a funcionar como uma fase pré-reflexiva que confere consistência e eficácia à ação. No nível pré-reflexivo no qual o corpo age, não existe uma planificação da ação como uma figuração consciente (representação mental). A ação simplesmente flui guiada pelo Umwelt (MERLEAU-PONTY, 2006b) de atuação e pelo gênero (CLOT, 2006). Em outras palavras, a ação é perceptivamente orientada (MERLEAU-PONTY, 2005). O Umwelt é o espaço de atuação do agente; espaço de percepçóes. Trata-se de um termo típico da cognição incorporada. O ser age e agindo cria o seu Umwelt de habitação sensoriomotora. O corpo, ao atuar no interior do Umwelt, se torna uma potencialidade de percepção, global, com sua espacialidade própria e 
motricidade (MERLEAU-PONTY, 2005, p. 129) que antecedem a todo o fenômeno das partes e todo fenômeno perceptivo.

A ideia da ação perceptivamente orientada é contrária à de representação mental. $\mathrm{Na}$ ação perceptivamente orientada, o modo como o agente age afeta as suas percepçóes, assim como estas afetam novamente a forma como ele age, num ciclo recorrente de ação-percepção. Por esse motivo, as percepçôes de quem se encontra acoplado no mundo de uma dada atividade são distintas daquelas de quem é externo ao acoplamento agente-mundo. O que é vivenciado pelos agentes, em sua experiência da atividade de trabalho, não é compreendido pelos atores de outros domínios de atuação. Isso gera severas dificuldades às possibilidades de intercompreensão.

Um artefato não é, em si mesmo, um instrumento para ação. Quem confere uma razão de existência para o artefato, fazendo-o ser instituído como instrumento, é o sujeito. Isso derruba a visão objetivista da atividade instrumental. São os sujeitos que conferem aos artefatos a propriedade de que necessitam, para se converterem em instrumentos. Uma atividade que aparenta ser puramente objetiva é, na realidade, subjetiva. O artefato é constituído como instrumento pelo próprio sujeito. Um instrumento não é, portanto, objetivamente instituído, mas subjetivamente construído pelo sujeito, que o torna singular para o alcance dos objetivos da ação. Isso equivale às palavras de Thompson (2007), quando afirma que o mundo é um projeto do sujeito (é projetado por ele), enquanto o sujeito é um projeto do seu mundo, o que Merleau-Ponty (2005, p. 108) denomina como ser do mundo e ser como situação. Trata-se de uma via pré-objetiva que chamaremos de ser do mundo. O reflexo não resulta de estímulos objetivos. É assim que posso dizer que meu corpo é uma forma, um fenômeno do qual o todo é anterior às partes (p. 129). Uma espacialidade de situaçáo, antes que uma espacialidade de posição. A função de um instrumento na ação é um constructo do sujeito e não uma propriedade do objeto em si.

Merleau-Ponty afirma que a relação entre o "eu" e o mundo não é a do sujeito-objeto, mas antes aquilo que ele chama, seguindo Heidegger, serno-mundo. Para um sujeito corpóreo, não é possível especificar o que é o sujeito abstraindo-se do mundo, nem é possível especificar o que é o mundo abstraindo-se do sujeito: o mundo é inseparável do sujeito, mas de um sujeito que não passa de um projeto do mundo, e o sujeito é inseparável do mundo, mas de um mundo que o próprio sujeito projeta. Pertencer ao mundo desta forma significa que a nossa principal forma de nos relacionarmos com as coisas não é puramente sensorial e reflexiva, nem 
cognitiva e intelectual, mas antes corporal e hábil. Merleau-Ponty chama este tipo de intencionalidade corporal de "intencionalidade motora" (THOMPSON, 2007, p. 287).

Não existe um mundo universalmente percebido, exterior ao agente e independente de sua ação. $\mathrm{O}$ mundo é um existencial, abrigo do corpo próprio dotado de espacialidade e motricidade, assinala Merleau-Ponty (2005). Ele existe apenas para um agente que nele habita com as potencialidades motoras do corpo, em sua espacialidade. É preciso existir, no sentido ativo do termo, para poder ter um mundo. Somente existindo e habitando o mundo com as potencialidades motoras e sensoriomotoras do corpo-agente (corpo fenomenal com sua espacialidade de situação e não apenas de posição) é que se pode falar da existência do próprio mundo. É precisamente nesse sentido que o mundo é um existencial: com sua espacialidade do corpo próprio e motricidade (MERLEAU-PONTY, 2005, p. 129). Não há como representá-lo, tal qual como ele é em si, uma vez que o sujeito se encontra acoplado ao mundo e não tem como dele se desvincular, para elaborar uma representação objetivista independente de sua incorporação a ele. Sujeito e mundo são mutuamente especificados (THOMPSON, 2007). Um sujeito age conforme uma clareira que é aberta pela sua própria ação. O caminho é construído pelo caminhar. Ele sabe como proceder, que gestos executar, que atitudes tomar, que decisóes adotar, graças ao gênero da atividade (CLOT, 2006), o qual oferece ao sujeito todos esses elementos, sem que ele precise elaborar um mapa mental ou representação em cada situação.

A noção de gênero foi criada por Clot (2006), sob inspiração da noção de gênero literário, enquanto categoria que orienta os estilos dos autores. Pertencer a um gênero é saber fazer orientado por uma estrutura maior que guia as condutas individuais, sem a necessidade de que cada um recrie toda a estrutura maior, a cada momento. $\mathrm{O}$ sujeito está numa posição de orientado por essa categoria maior que o orienta. Ele não perde sua identidade, mas encontra apoio para sua ação individual, concedido pela noção de gênero. A relação entre sujeito e gênero é a de orientação. $O$ gênero orienta o sujeito sobre como agir. A ação simplesmente flui em sintonia com o contexto. Não existe planificação mental da ação, pois a ação transcorre, sem um planejamento criativo objetivo, porém, na dimensão pré-reflexiva em que o corpo no trabalho atua. Essa dimensão pré-reflexiva é amparada pelo gênero, sendo a 
instância que é anterior a qualquer decisão consciente, a qual, na maioria das vezes, nem chega a se concretizar (conscientemente).

Para um agente familiarizado com o gênero (ou Umwelt), não é necessário planificar conscientemente a ação ou a atividade, visto que o gênero vai guiá-las de modo espontâneo, poupando a mente de ter que elaborar conscientemente todos os gestos ou atos, a cada vez que a situaçáo se apresenta. Diante do gênero, as situações são familiares, na maioria das vezes, uma vez que o gênero é o repertório coletivo de ações e avaliaçóes pressupostas (CLOT, 2006). Antes que o operador formule a pergunta de como agir, o gênero já oferece a resposta no nível pré-reflexivo, permitindo que a ação seja concluída em harmonia com o que a situação exige, sem uma planificação mental ou mapa mental que represente a açáo correta. $\mathrm{O}$ gênero funciona de maneira econômica ou, em outras palavras, economizando a mente do operador de ter que elaborar uma representaçáo mental. Incorporado em seu gênero, o operador realiza a atividade no plano pré-reflexivo descrito por Merleau-Ponty (2005). As formas possíveis de agir, os modos de ação possíveis e viáveis, são todos disponibilizados ao operador pelo seu gênero de atuação ou Umwelt.

O sentido da ação é, na realidade, um sentido sensoriomotor. A "intencionalidade motora" (PACHOUD, 1999; THOMPSON, 2005, 2007) é a abertura ou direcionamento da consciência, em direção aos objetos visados, estruturado pela potencialidade motora do corpo, como uma camada pré-objetiva e pré-reflexiva que antecede a própria reflexão ou tomada de consciência (THOMPSON, 2005). Trata-se do "ser bruto" já abordado pela fenomenologia de Maurice Merleau-Ponty. O ser bruto é algo distinto da consciência. Ele é o corpo próprio dotado de espacialidade e de motricidade (MERLEAU-PONTY, 2005). Trata-se de um modo de existência que antecede a consciência e guia a açáo, sem que o sujeito tenha a necessidade de planificar a ação, ou seja, elaborar uma representação mental. $\mathrm{O}$ ser bruto envolve o corpo dotado de esquemas de ação, os quais permitem agir sem representar. E os esquemas são assimilados ao longo de uma história de pertencimento a uma dada atividade (Umwelt). O ser bruto vive (existe) num nível pré-objetivo e pré-reflexivo anterior à atividade reflexiva e à tomada de consciência. O corpo fenomenal é o ser bruto merleau-pontyano. Por outro lado, é uma construção de sentido (no sentido construtivista) do tipo Umwelt. Eu não preciso compreender peça por peça para compreender o jogo, pois eu o compreendo em sua inteireza, pela visão global do todo. Ou seja, Umwelt, de Uexküll, abordado na fenomenologia de Merleau-Ponty, enquanto sentido 
construído, que emerge pelos movimentos sensoriomotores de regulação da situação (MERLEAU-PONTY, 2006b).

$\mathrm{Na}$ noção de affordance, compreende-se melhor a afirmação de Thompson (2007) de que o mundo é um projeto do sujeito, assim como o sujeito é projetado pelo seu mundo. Ou seja, o ato vai ao encontro de um mundo que é projetado pelo sujeito e adequado ao seu uso, assim como a potencialidade motora do sujeito é um projeto do mundo sobre suas estruturas corporais. Isso traz à tona a ideia de affordance, segundo a qual o mundo encontra sentido na sensoriomotricidade do agente, na intencionalidade motora do corpo, sem necessidade de passar por uma representação mental ou, nas palavras de Thompson (2007, p. 288):

Ao mesmo tempo, as coisas à minha volta, como chávenas de chá, teclados de computador e maçanetas de porta têm sentidos ou significados motores, aquilo que Gibson (1979) designa por "affordances", que desencadeiam açóes apropriadas. As coisas no mundo produzem açóes intencionais adequadas e projetos motores por parte do sujeito (o sujeito é um projeto do mundo), mas as coisas no mundo só têm sentidos motores específicos ou affordances em relação às habilidades motoras do sujeito (o mundo é projetado pelo sujeito). Este circuito de intencionalidade motora corpomeio ambiente pertence àquilo que Merleau-Ponty designa por "arco intencional" que subtende a vida da consciência, que integra sensibilidade e motilidade, percepção e ação.

Pela noção de affordance, não é necessário que as coisas tragam uma etiqueta, em si, sobre que uso fazer delas. A compreensão do uso é instantânea e vai ao encontro dos esquemas corporais (sensoriomotores) do sujeito. A potência motora do corpo é que guia o uso dos objetos em conformidade com as affordances.

Os esquemas corporais também são um projeto do mundo sobre o sujeito. É em função deles que o aspecto sensoriomotor da atividade adquire um sentido latente. Faz-se sem o saber, sem o dizer, sem o representar. Vai-se ao encontro do mundo objetivo, por intermédio desses esquemas corporais que orientam a ação em conformidade com o gênero. Ao mesmo tempo, o mundo já possui uma forma que é adequada aos esquemas (bem exemplificado pela noção de affordance). Essa união harmoniosa entre o corpo e o instrumento de trabalho se dá na dimensão sensoriomotora, a vincular os aspectos objetivos do objeto aos esquemas corporais do agente. Ao habitar o gênero (Umwelt), durante um período de sua história, o agente assimila e acomoda esquemas 
corporais vitais para a concretizaçáo da atividade de trabalho, a qual se efetua na dimensão sensoriomotora. Trata-se de um sentido dinâmico da situação, configurado pelo aspecto do movimento do corpo em ação, sem uma mediação simbólica ou de processamento de informação abstrata. O Umwelt é esse repertório de açóes possíveis que permite ao agente executar tarefas dentro do seu mundo de atuação e que adquire sentido pela intencionalidade motora (PACHOUD, 1999) e pela sensoriomotricidade.

Os esquemas se ajustam ao objeto, no transcorrer da ação, dentro do que se denominará aqui racionalidade sensoriomotora da ação. A explicação de um dado ato não está no recebimento de inputs objetivos, tratados no interior do sistema para posterior emissão dos outputs. Não há inputs nem outputs, porque o sistema é fechado organizacionalmente. Os outputs e inputs existem apenas sob o ponto de vista do observador. $\mathrm{Na}$ ação, essa racionalidade sensoriomotora guia os atos no fluxo da transparency (VARELA, 1999), conforme já frisado, a integrar o ato, o movimento e o instrumento, sem a ocorrência de uma representação interna correspondente ao mundo exterior. $\mathrm{O}$ mundo exterior somente adquire sentido para o agente, por intermédio de seu movimento. A ação perceptivamente orientada (MERLEAU-PONTY, 2005) é dependente dos movimentos do agente. A cognição incorporada é dinâmica, no sentido do dinamismo dos movimentos do agente em seu meio ambiente de atuação (que também é um recorte do meio ambiente em geral, dependente dos movimentos ou Umwelt). Esse recorte do mundo pela sensoriomotricidade é o Umwelt do agente. Aquilo que faz sem o dizer, sem planificar, sem elaborar representação mental. Algo como um repertório para a ação eficaz. O Umwelt tem a propriedade de proteger o agente de sua própria ação individual. Portanto, age-se e logo se percebe, para, posteriormente, agirse, num ciclo recorrente de especificação mútua entre ação e percepção. $\mathrm{O}$ sujeito se encontra absorvido pelo contexto, num processo não-reflexivo. Ação e percepção se completam mutuamente, não havendo espaço para uma elaboração proposicional entre elas.

Esse meio ambiente particular emerge como um mundo sensoriomotor, através da atualização do organismo como ser sensoriomotor:

[...] os sistemas autônomos não operam com base em representaçóes internas no sentido subjetivista/objetivista. Em vez de representarem internamente um mundo externo num sentido cartesiano, representam um meio inseparável da sua própria estrutura e ações. [...] Em linguagem fenomenológica, constituem (revelam) um mundo que tem o selo da sua própria estrutura. No dizer de Merleau-Ponty, citando Goldstein [...] o 
meio emerge do mundo através da existência ou atualização do organismo. No caso da vida animal, o meio emerge como um mundo sensório-motor.

$\mathrm{O}$ organismo é um ser sensório-motor graças ao seu sistema nervoso (THOMPSON, 2007, p. 80).

\section{Thompson (2007, p. 81) continua, elaborando a noção de Umwelt:}

Esta ideia de um mundo sensório-motor - um mundo de percepção e ação orientado para o corpo - não é mais do que a noçáo original de Umwelt proposta por Uexküll. Um Umwelt é o meio de um animal no sentido do seu mundo vivido e fenomenal, o mundo como se apresenta a esse animal graças ao seu repertório sensório-motor.

O Umwelt é o mundo sensoriomotor de percepção e ação orientado para o corpo, mundo vivido e fenomenal. Mundo de pertencimento do agente, que cria sentido para sua ação e possibilita a sua percepção num modo de ação perceptivamente orientada.

Segundo Merleau-Ponty (2006a), o comportamento é a causa primeira das estimulações. Todas as estimulaçóes que o organismo encontra só são possíveis pelos seus movimentos precedentes, que culminam na exposição do órgão receptor às influências externas. Os estímulos sensoriais que o organismo encontra dependem diretamente do seu comportamento motor, enquanto a maneira como o organismo se move depende diretamente das consequências sensoriais dos seus comportamentos anteriores:

Mas, do mesmo modo como todas as estimulaçóes que o organismo recebe foram possíveis apenas por seus movimentos precedentes, que acabaram por expor o órgáo receptor às influências externas, poderíamos dizer também que o comportamento é a causa primeira de todas as estimulaçōes. Assim, a forma do excitante é criada pelo próprio organismo, por sua maneira peculiar de se oferecer às açōes do exterior. Sem dúvida, para poder subsistir, ele deve encontrar em torno de si um certo número de agentes físicos e químicos. Mas é ele, segundo a natureza própria de seus receptores, segundo os patamares de seus centros nervosos, segundo os movimentos dos órgáos, que escolhe no mundo físico os estímulos aos quais será sensível. $\mathrm{O}$ meio se recorta no mundo segundo o ser do organismo - dado que um organismo pode ser apenas se encontra no mundo um meio adequado (MERLEAU-PONTY, 2006a, p. 14-15). 
Merleau-Ponty (2006a) traz acima as palavras de Goldstein, o qual reforça o caráter antirrepresentacionalista da sua obra. Assim como Uexküll, também Goldstein é citado largamente pelo autor francês. Em face da ideia de um mundo que existe apenas para um ser que o habita, tem-se que o meio se recorta no mundo segundo o ser do organismo.

Em todos os agentes, as redes neuronais estabelecem e mantêm um ciclo sensoriomotor pelo qual aquilo que o agente sente depende da forma como se move, e a forma como se move depende daquilo que sente. Não há nenhum agente que seja um mero respondente passivo, pois ele se relaciona com o meio, nos seus próprios termos sensoriomotores. As estimulaçóes jamais poderiam ser recebidas sem os movimentos mediante os quais são expostos os receptores à sua influência. Todas as estimulaçóes que o organismo recebe somente são possíveis pelos seus movimentos anteriores, os quais culminam na exposição do órgão receptor às influências externas: o comportamento é a causa primeira de todas as estimulaçóes (MERLEAU-PONTY,2006a). É o próprio organismo que cria a forma do excitante, pela sua maneira de se entregar às ações exteriores. É igualmente o próprio organismo, de acordo com a especificidade da natureza dos seus receptores, que define no mundo físico os estímulos aos quais será sensível. O meio ambiente do organismo (Umwelt) emerge do mundo pelo ser-no-mundo do organismo (MERLEAU-PONTY, 2006b). Falar em Umwelt significa falar em sensoriomotricidade do corpo próprio, atuante, no interior do seu mundo comum dotado de percepção ou de ação perceptivamente orientada.

Não há, por conseguinte, como se postular a ideia de representação mental como um espelhamento de um mundo objetivo por sujeitos distintos, uma vez que o mundo é um existencial, ou seja, onde habita o corpo fenomenal e não apenas o corpo objetivo (MERLEAU-PONTY, 2005, p. 136), uma construção particular de sujeitos singularmente situados no "seu ambiente" de ação incorporada em situaçóes específicas da atividade em curso. Postular a ideia de representação mental significaria afirmar que agentes distintos, situados em "mundos distintos" ou Umwelts distintos (MERLEAU-PONTY, 2006b), perceberiam os mesmos fatos de forma idêntica. Isso não ocorre.

\section{A noçáo de $U_{M W E L T}$ em Merleau-Ponty}

Um ambiente cognitivo comum, ou um referencial operativo comum no mundo do trabalho: um gênero (CLOT, 2006) ou Umwelt (MERLEAU- 
PONTY, 2006b). Uma interface entre o mundo do "em si" e o mundo do "para-si". Um universo de recorte (derivado do comportamento) construído pela atuação do agente (ser vivo). Uma unidade de análise que rompe com a ideia objetivista de representação mental do mundo como espelhamento do ambiente externo pela mente. Essas frases possibilitam um esboço inicial da noção de Umwelt em Merleau-Ponty (2006b). O Umwelt é uma espécie de mundo comum (PASTRÉ, 2005) ou gênero (CLOT, 2006) partilhado por aqueles que exercem uma mesma atividade de trabalho. Trata-se da parcela da realidade vivenciada comumente:

O Umwelt marca a diferença entre o mundo tal como existe em si e o mundo enquanto mundo de tal ou tal ser vivo. É uma realidade intermediária entre o mundo tal como existe para um observador absoluto e um domínio puramente subjetivo. [...] É o meio ambiente de comportamento "oposto ao meio ambiente geográfico", para usarmos as palavras de Koffka. Uexküll antecipa a noção de comportamento. Quando se trata do Umwelt, não se faz especulação psicológica, sustenta ele (MERLEAU-PONTY, 2006b, p. 271).

Como será apresentado a seguir, a noção de Umwelt possui uma primazia em relação à noção de consciência. A consciência emerge no interior do Umwelt de atuação (ação incorporada/comportamento) do agente, em seu acoplamento sensoriomotor sujeito-mundo ou arco intencional: "Essa atividade comportamental orientada para um Umwelt começa muito antes da invenção da consciência” (MERLEAU-PONTY, 2006b, p. 271).

A crítica ao objetivismo e ao idealismo é clara, nos termos de MerleauPonty (2006b, p. 272): "Uexküll denuncia a dicotomia cartesiana, que alia uma maneira de pensar extremamente mecanicista a uma maneira de pensar extremamente subjetiva”.

É difícil não encontrar um trecho sequer no pensamento de MerleauPonty que não faça referência ao antirrepresentacionalismo. Um corpo que age, um comportamento que cria o seu próprio mundo de atuação e percepção. A tese merleau-pontyana é verdadeira e a do representacionalismo é falsa. A força de tal afirmação vem também de sua potencialidade empírica, trazida pela ciência cognitiva contemporânea, em seu movimento de naturalização da fenomenologia, inclusive a de Husserl.

A primazia ontológica do Umwelt na modulação dos eventos cognitivos, numa visão antirrepresentacionalista merleau-pontyana, é dada pelos trechos do pensamento de Uexküll que despertam o interesse do filósofo francês: 
“[...] Uexküll apresenta o Umwelt como um tipo do qual a organização, a consciência e a máquina são meras variantes" (MERLEAU-PONTY, 2006b, p. 272). Conforme anteriormente afirmado, novamente o filósofo ressalta a primazia do Umwelt (ambiente de atuação/incorporação/comportamento) em relação à consciência.

A ideia de um Umwelt dos animais superiores demonstra a expansão de um conceito biológico, atrelado à própria noção de ser vivo, para uma visão de um constructo engendrado na partilha social e histórica dos ditos "animais" ("animais", em Uexküll, mas agentes (sujeitos), em Merleau-Ponty). As interpretaçôes dos agentes (operadores) situados no interior do Umwelt (mundo comum interno do trabalho, gênero ou ambiente de atuação) são radicalmente distintas daquelas dos observadores situados em seu exterior. $\mathrm{O}$ mundo exterior é re-formulado na interioridade do agente ("animal") e na interioridade de um Umwelt (função de enquadramento), jogando por terra a ideia de um mundo predeterminado, enquanto fonte de dados sensoriais que seriam passivamente captados por um sujeito universal e ideal:

Estamos diante de um fenômeno novo: a construçáo de um Gegenwelt. [...] No estágio dos animais superiores, o Umwelt deixa de ser fechamento para ser abertura. $\mathrm{O}$ mundo é possuído pelo animal. $\mathrm{O}$ mundo exterior é "destilado" pelo animal que, diferençando os dados sensoriais, pode responder-lhes por açôes finais, e essas reaçóes diferençadas só são possíveis porque o sistema nervoso monta-se como uma réplica do mundo exterior (Gegenwelt). [...] Nessa perspectiva, a disposição do mundo exterior, o universo objetivo, desempenha doravante mais o papel de signo que de causa (MERLEAU-PONTY, 2006b, p. 276-277).

A ideia de Umwelt como um meio ambiente de recorte, como uma construção da atuação, é ressaltada em diferentes passagens dos textos de "A Natureza":

$\mathrm{O}$ animal superior constrói, portanto, um Umwelt que tem um Gegenwelt, uma réplica em seu sistema nervoso. Em sua obra de 1934, Uexküll precisa essa noção de Gegenwelt. Distingue o Welt: é o mundo objetivo; o Umwelt: é o meio ambiente que o animal conquista para si, e o Gegenwelt, que é o Umwelt dos animais superiores. [...] Uexküll mostra que o espaço humano compóe-se de três espaços que se imbricam: o espaço visual, o espaço tátil e o espaço de ação (MERLEAU-PONTY, 2006b, p. 279-280). 
O Umwelt é a região que transcende o espaço físico, na qual se encontra estruturalmente acoplado o sujeito cognitivo em seu Dasein (HEIDEGGER, 2005): o seu exercício existencial de "ser-no-mundo" enquanto atuação, nesse seu ambiente singular (Umwelt), recortado no mundo por essa sua atuação (ação incorporada). Eu existo enquanto Dasein, enquanto ser que exerce o seu projeto de existência numa modalidade do tipo ser-no-mundo. Sob a égide da fenomenologia de Heidegger (2005), no que existe de sintonia com Merleau-Ponty, pode-se afirmar que a existência é transcendência como "serno-mundo" (Dasein). Numa ontologia fundamental, enquanto analítica do Dasein, este último é o ente que compreende o ser; é o ente metafísico por excelência. Já o Umwelt é esse seu espaço fenomenológico, que antecede o fenômeno da percepção global, numa concepção de conjunto na qual as peças somente adquirem sentido, quando confrontadas com o todo. Ou campo de atuação, no qual o Dasein existe incorporado, em ação. Esse campo global, unificador de percepção e constituição da realidade, é uma construção, com o poder de produzir e conservar o próprio agente cognitivo e sua organização interna (MATURANA; VARELA, 2002). Ele possui uma temporalidade e uma espacialidade específicas:

Deve-se compreender a vida como a abertura de um campo de açóes. O animal é produzido pela produção de um meio, ou seja, pelo aparecimento, no mundo físico, de um campo radicalmente diverso do mundo físico, com sua temporalidade e sua espacialidade específicas (MERLEAUPONTY, 2006b, p. 281).

Ou, como destacado anteriormente, a existência é essa transcendência (em relação ao mundo físico) como "ser-no-mundo": Dasein (HEIDEGGER, 2005), no interior de um Umwelt. Qualquer estímulo será reformulado pelo caráter ativo do agente, seu "ser-no-mundo" (enquanto movimento, ação, atuação: Dasein). Isso também é enfaticamente afirmado por Husserl, em sua noção de Leibhaftigkeit (PACHOUD, 1999). Maurice Merleau-Ponty, E. Husserl e M. Heidegger convergem em vários aspectos de suas obras (divergências à parte, há pontos de convergência, quando enxergadas essas distintas obras destes, sob o prisma da noção mais ampla de fenomenologia). Este e outros termos do pensamento de Husserl já foram naturalizados pela ciência cognitiva contemporânea. Assim como em Merleau-Ponty, Leibhaftigkeit refere-se à sensoriomotricidade, ao movimento na constituição do objeto de percepção e à cinestesia. Cinestesia, percepção sensório-motora e movimento perceptivo são resumidos nas expressões husserlianas Leibhaftigkeit 


\section{I kinesthetic sensations (PACHOUD, 1999). Leibhaftigkeit é do tipo percepçäo} incorporada. Dasein é o ser-no-mundo.

O comportamento exerce essa funçáo primordial de reenquadramento do estímulo exterior (MERLEAU-PONTY, 2006a), o que integra exterior/ interior; subjetivo/objetivo; sujeito/objeto (instrumento) - numa compreensão global (de conjunto), ou circunvisão - Umsicht (HEIDEGGER, 2005) ou transparency (VARELA, 1999), que não resulta de uma relação de causalidade.

$\mathrm{O}$ Umwelt estabelece uma relaçấo de sentido entre situaçáo e movimento, em uma situação de conjunto e visão integrada ação/instrumento - Umsicht. Observe-se que, no final da citação abaixo, há a afirmação de que o Umwelt é o mundo implicado pelos movimentos (e comportamento) do animal (agente cognitivo); e que regula seus movimentos, por sua estrutura própria:

Não há nenhuma estimulação vinda de fora que não tenha sido provocada pelo movimento próprio do animal. Cada açáo do meio é condicionada pela ação do animal; a conduta do animal suscita respostas por parte do meio. [...] Em suma, o exterior e o interior, a situação e o movimento, não estáo numa relação simples de causalidade, e não podem ser traduzidos em termos de "causalidade ímpeto" do antes ao depois. O comportamento não pode ser compreendido se o compreendermos instante por instante. [...] Cada parte da situação só age como parte de uma situação de conjunto: nenhum elemento de açáo tem, de fato, utilidade separada. Entre a situação e o movimento do animal, há uma relação de sentido que a expressão Umwelt traduz. O Umwelt é o mundo implicado pelos movimentos do animal e que regula seus movimentos por sua estrutura própria (MERLEAU-PONTY, 2006a, p. 283-284).

Merleau-Ponty enterra a crítica que poderia receber de uma suposta aproximaçáo com o solipsismo, ou subjetivismo, ao afirmar que a partilha entre Umwelts diferentes é possível, já que um agente vive um no Umwelt do outro. Essa noção é a abertura para a compreensão da intersubjetividade (PACHOUD, 1999). A explicação dessa vivência de um Umwelt pelo outro náo é fornecida na obra em questáo, mas é a tônica de outros textos do filósofo francês. Suas condiçôes de acontecimento já surgiam bem delineadas, em "Fenomenologia da Percepção". Entretanto, a afirmação quanto a isso é clara e objetiva, também, em "A Natureza": "O desenvolvimento de um Umwelt por um outro é requerido pelo seu. Também nós, homens, vivemos cada um no Umwelt do outro" (MERLEAU-PONTY, 2006b, p. 287). 
Em outro aspecto, o termo Umwelt torna o conceito de consciência algo incorporado ao contexto vital, ao contrário de algo abstrato, pautado pela noção de representação mental. A citação abaixo reafirma esse ponto. Isso faz referência, ainda, ao caráter recorrente dos princípios da incorporação (encarnação) na obra de Merleau-Ponty como um todo, ou seja, seu antirrepresentacionalismo e anticognitivismo (contrários ao realismo representativo, ao objetivismo e ao idealismo). Na citação abaixo, há também, novamente, um viés antissolipsista, ao se enfatizar que o Umwelt humano é um campo aberto: "Uma consciência é aquilo que se pode chamar de um 'campo transcendental', um campo que valoriza o conjunto dos campos vitais. O Umwelt humano é um campo aberto" (MERLEAU-PONTY, 2006b, p. 288). A ciência cognitiva contemporânea soa afinada com o pensamento de MerleauPonty, em seu antirrepresentacionalismo e antirrealismo representativo.

Nesse mesmo sentido, ressalta novamente os caracteres de transespacial e transtemporal (anteriormente descritos) de um Umwelt, ou mundo de interface, construído pela atuação/ação incorporada (encarnação), incluindo o comportamento ativo do agente:

O sujeito animal é sua realização "transespacial e transtemporal". [...] A noção de Umwelt já não nos permite considerar o organismo em sua relação com o mundo exterior, como um efeito desse mundo exterior, ou como uma causa. O Umwelt não se apresenta diante do animal como uma meta, não está presente como uma ideia, mas como um tema que obceca a consciência (MERLEAU-PONTY, 2006b, p. 289).

Ou seja, o organismo não é um objeto processador de estímulos de um mundo exterior (objetivismo, representação mental), mas um agente incorporado a re-enquadrar os estímulos sob a perspectiva de sua ação (e comportamento), a vivenciar. Além disso, torna-se claro que a consciência está incorporada no Umwelt de atuação/incorporação do agente (organismo), não sendo uma ideia (idealismo), nem uma composição de representaçôes mentais simbólicas (objetivismo/representacionalismo), todavia, um produto do próprio Umwelt que "obceca a consciência" (citação anterior), na experiência incorporada das vivências. 


\section{CONSIDERAÇÓES FINAIS}

O pensamento de Merleau-Ponty é bem conhecido, na ciência cognitiva contemporânea (CC), como fundamento do antiobjetivismo e do antirrepresentacionalismo (THOMPSON, 2005, 2007). Assim como sustentado na CC, em Merleau-Ponty náo existe espaço para a ideia de algo como uma representação mental que espelhe, no fundo da mente, um mundo preexistente e independente do sujeito.

O corpo possui uma potencialidade motora e sensoriomotora para a ação, a qual ocorre no nível pré-reflexivo ou conforme aquilo que MerleauPonty denomina ser bruto e corpo fenomenal, com sua espacialidade e motricidade (MERLEAU-PONTY, 2005, p. 129). Nesse nível, não se tem uma consciência reflexiva transitiva, porém, uma autoconsciência corporal pré-reflexiva dotada de intencionalidade motora (THOMPSON, 2007). Isso contradiz a ideia de representação mental. Os agentes não estão a elaborar mapas mentais correspondentes ao mundo exterior, independentemente deles, mas estáo, de fato, vivenciando (por dentro) o seu mundo de atividades.

O ser-no-mundo de Heidegger (2005) mostra que o mundo não é predeterminado, mas é um mundo conquistado pelo agente, por meio de sua ação sensoriomotora: trata-se de um Umwelt (MERLEAU-PONTY, 2006b). $\mathrm{O}$ mundo de ação, de cada um, não é universal e idêntico para todos, pois depende do tipo de atividade em que cada um se encontra envolvido.

O corpo é o ser bruto do qual nos fala Merleau-Ponty. Ele não é um objeto, como os demais do mundo físico; ele é um corpo fenomenal, unidade vivida que habita um mundo vivido, no qual se dá o fenômeno da percepção e da atuação. O corpo é uma potência perceptiva. Náo uma potência perceptiva que capta inputs universais do mundo material, mas uma unidade perceptiva que seleciona, no meio, pela sensoriomotricidade e pela intencionalidade motora, aquilo que será percebido.

O mundo depende do sujeito e, para falar num nível mais conceitual, utilizando um termo que os cientistas da cognição tomaram de empréstimo da fenomenologia, a leitura do mundo pelo sujeito depende de sua intencionalidade motora (MERLEAU-PONTY, 2005; THOMPSON, 2005; PACHOUD, 1999). Em outras palavras, o mundo é inseparável do sujeito; um sujeito incorporado que é projetado pelo mundo em que enage ("enact", VARELA, 1999). Em contrapartida, o sujeito é inseparável do mundo, entretanto, de um mundo que é uma projeção do próprio sujeito 
incorporado. Isso recebe o nome de mútua especificação sujeito-mundo, um conceito fundamental da cognição incorporada (ciência cognitiva) e da obra de Merleau-Ponty. Em decorrência disso, vem que nossa forma de compreender o mundo não é, inicialmente, nem puramente sensorial ou reflexiva, nem cognitiva ou intelectual; ela é corporal e motora ou, para falar como MerleauPonty e os cientistas cognitivos, decorre da nossa intencionalidade motora (MERLEAU-PONTY, 2005; THOMPSON, 2005; PACHOUD, 1999).

BOUYER, G. C. The anti-representationalist character of cognition in Merleau-Ponty's thought. Trans/form/ação, Marília, v. 43, p. 145-166, 2020. Edição Especial.

\begin{abstract}
This article defends the view that the foundations of contemporary cognitive science (CC) are in tune with Merleau-Ponty's thinking in its anti-objectivist and anti-representationalist aspects. The idea of mental representation is contested both in CC and in Merleau-Ponty's thinking. Cognition does not mirror an outside world independent of embodied subjects. The world is an existential one as Merleau-Ponty and the CC say. The mental representation hypothesis assumes that the world can be perceived independently of the perceiving subject. This is not true. Perception depends on how the subject acts in his perceived world. All the stimulations that the organism finds are only possible by its previous movements that result in the exposure of the receiving organ to external influences. The sensory stimuli that the organism finds depend directly on its motor behavior and the way the organism moves depends directly on the sensory consequences of its previous behaviors.
\end{abstract}

Keywords: Merleau-Ponty. Mental representation. Cognitive science.

\title{
REFERÊNCIAS
}

CLOT, Yves. A Funçáo psicológica do trabalho. Petrópolis: Vozes, 2006.

GIBSON, Jean. J. The ecological approach to visual perception. Boston: Houghton Mifflin, 1979.

HEIDEGGER, Martin. Ser e tempo. Petrópolis: Vozes, 2005.

MATURANA, Humberto; VARELA, Francisco. De máquinas e seres vivos: Autopoiese - a organizaçáo do vivo. Porto Alegre: Artes Médicas, 2002.

MERLEAU-PONTY, Maurice. Phénoménologie de la perception. Paris: Gallimard, 2005.

MERLEAU-PONTY, Maurice. A Estrutura do comportamento. São Paulo: Martins Fontes, 2006a. 
MERLEAU-PONTY, Maurice. A Natureza. São Paulo: Martins Fontes, 2006 b.

PACHOUD, Bernard. The teleological dimension of perceptual and motor intentionality. In: PETITOT, Jean.; VARELA, Francisco.J.; PACHOUD, Bernard.; ROY, Jean Michel.

(Orgs.). Naturalizing Phenomenology: issues in contemporary phenomenology and cognitive science. Stanford: Stanford University Press, 1999, p. 196-219.

PASTRÉ, Pierre. La conception de situations didactiques à la lumière de la théorie de la conceptualisation dans l'action. In: RABARDEL, Pierre; PASTRÉ, Pierre (Orgs). Modèles du sujet pour la conception: dialectiques activités développement. Paris: Octarès, 2005. p. 73-107.

THOMPSON, Evan. Sensorimotor subjectivity and the enactive approach to experience. Phenomenology and the Cognitive Sciences. v. 6, n. 3, p. 6-27, 2005.

THOMPSON, Evan. A mente na vida: biologia, fenomenologia e ciências da mente. Lisboa: Instituto Piaget, 2007.

VARELA, Francisco. J. Conhecer: as Ciências Cognitivas, tendências e perspectivas. Lisboa: Instituto Piaget, 1994.

VARELA, Francisco. J. The specious present: a Neurophenomenology of time consciousness. In: PETITOT, Jean. et al. (Org.). Naturalizing phenomenology: issues in contemporary Phenomenology and cognitive science. Stanford: Stanford University Press, 1999. p. 266-314.

Recebido: 28/02/2018

Aceito: 23/02/2020 
BOUYER, G. C. 